Damir BOŠNJAKOVIĆ

JU Osnovna škola , Vozuća“

E-mail: damirbosnjakovic@hotmail.com

Stručni rad/Professional article

UDK/UDC: 94(497:497.6)"18/20" (051)

\title{
HISTORIJSKI POGLEDI // HISTORICAL VIEWS, God. II, br. 2, Centar za istraživanje moderne i savremene historije Tuzla, Tuzla 2019, 485 str.
}

U vremenu sve učestalije pristrasnosti u historijskoj nauci, te očevidne naklonjenosti određenim političkim interesima što za posljedicu ima odstupanje od metodoloških pravila pisanja, blagodat je imati pred sobom drugi broj časopisa Historijski pogledi. Osim predgovora, gdje je ukazano na relevantnost pokretanja

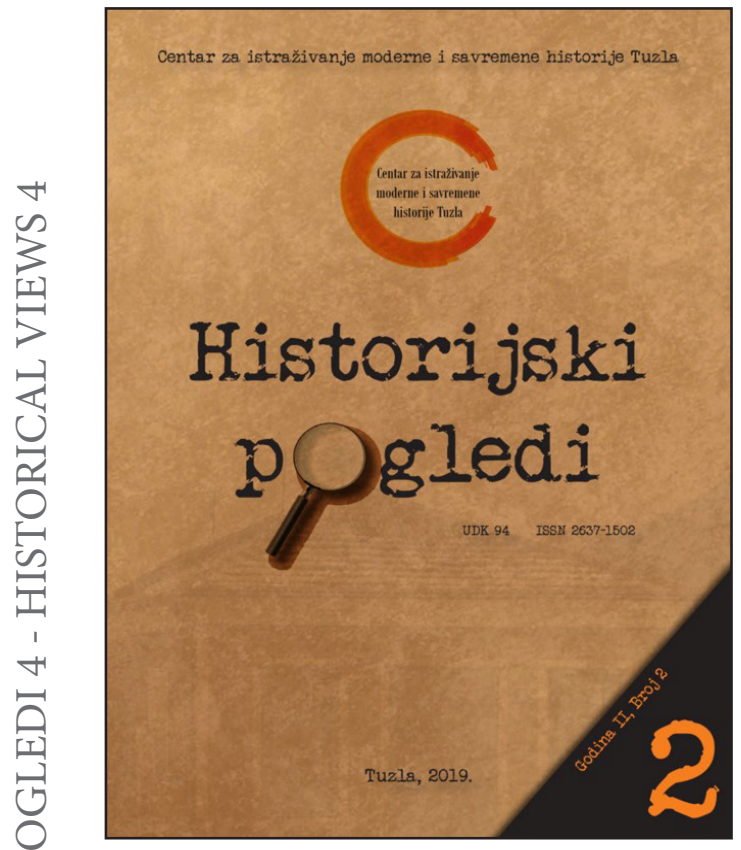
časopisa, prvi dio Historijskih pogleda, donosi 20 radova eminentnih, kako domaćih tako i istraživača iz regiona, koji se odnose na modernu i savremenu historiju. Ovi autori su profesionalni historičari, sociolozi i politolozi čiji su radovi daleko od ideologiziranja istraživačkog pitanja, što je eksplicitni primjer i škola, kako studentima, tako i nekim „pozicioniranim“ historičarima u Bosni i Hercegovini. Svih 20 radova, (4 Pregledna te 16 Izvornih naučnih radova), se nalaze u rubrici Članci (5-429).

Prvi rad u ovom broju Historijskih pogleda donosi prof. dr. Adib Đozić pod naslovom Hadži Husejn eff. Đozić Ruhi kadija iz Srebrenice i Nikšićki naib (7-32). Kao teorijsko-metodološko polazište za ovaj rad autor navodi stav Emila Durkheima izrečen još 1908. godine: „Ne postoji ništa u mom sociološkom znanju da je vrijedno tog imena što ne bi imalo historijski karakter. Ne postoje dva metoda ili dva shvaćanja. Ono što je istina za historiju biće i za sociologiju." S tim u vezi, autor je na osnovu historijskih izvora prvog reda i, kako on kaže, vrlo vjerodostojnog usmenog porodičnog sjećanja, napisao tekst o Hadži Husejnu eff. Đoziću, kadiji iz Srebrenice iz druge polovine 19. stoljeća. Osim uvodnih napomena, rad sadrži 
kraću biografiju kadije hadži Husejna eff. Đozića Ruhi, zatim izvještaj Husejn Ruhi Efendije (Đozića) o opsadi Nikšića 1877. godine, te nekoliko značajnih društvenohistorijskih činjenica iz sidžila Srebrenica iz 1887.godine. Na kraju, autor donosi zaključak iz kojeg izdvajamo da je kadija hadži Husejn eff. Đozić Ruhi učestvovao u najznačajnijim pitanjima rada i razvoja Ljubinja, Nikšića i Srebrenice, gradova za koje se zna da je u njima službovao, te da je bio istinski poliglota te vrstan odgajatelj i učitelj koji je izveo nekoliko generacija softi (učenika) u oblasti tesavvufa, Nakšibendijskog tarikata.

Rad dr. sc. Safeta Bandžovića pod naslovom Nedovršena prošlost $u$ vrtlozima balkanizacije: refleksije , istočnog pitanja“ u historijskoj perspektivi (33-71) samim svojim naslovom upućuje na potrebu svestranijeg sagledavanja historijskih tokova na Balkanu u XIX i XX stoljeću, pa i onih u Bosni i Hercegovini. $\mathrm{S}$ tim u vezi, autor napominje da procesi dugog trajanja nadmašuju različite vremenske periode i prostorne granice i da se to odnosi i na sadržaj reljefnih dionica „Istočnog pitanja“. Na kraju, autor ovog rada nam daje težak zadatak, a to je uklanjanje evidentnih predrasuda i negativnih stereotipa koji se, kako sam kaže, tradicionalno artikuliraju $i$ unose u historiografiju.

Dr. sc. Zećir Ramčilović piše o temi Demografske promjene nakon Berlinskog kongresa (1878) u Bosni i Hercegovini (72-84). Autor nas prvo upoznaje sa odlukama Berlinskog kongresa, naročito članom 25. Berlinskog ugovora, te samom okupacijom i njenim demografskim posljedicama. Kroz prizmu popisa stanovništva austrougarske i osmanske (salname) provenijencije autor, u radu, prikazuje konkretne demografske promjene u Bosni i Hercegovini krajem XIX i početkom XX stoljeća. Posebnu metodološku ljepotu čini tabelarni prikaz vjerske strukture stanovništva Bosne i Hercegovine od 1870. do 1910. godine. Radi se o prikazu stanovništva Vilajeta Bosne (1870) po provincijama, zatim prikazu religiozne strukture stanovništva napravljene na bazi podataka austro-ugarskih popisa stanovništva po godinama njihovog održavanja, te strukturi stanovništva po religijskoj pripadnosti grada Sarajeva. Umjesto zaključka, autor na kraju rada iznosi posljedice demografskih promjena od kojih izdvajamo ozbiljnu prijetnju da u Bosni i Hercegovini jedna autohtona i dominantna populacija bošnjačkog naroda postane pasivizirana manjina u svojoj domovini i time izgubi i pravo da bude nosioc suvereniteta državnosti Bosne i Hercegovine.

Briga za narod u dijaspori do latentnog sukoba sa domicilnim narodom - aktualizacija prošlosti na sadašnjost u Bosni i Hercegovini rad je autora prof. dr. Ivana Balte (85-119). Strukturu rada čine dva podnaslova: „Projekt tzv. mađarske Julijanske akcije od Slavonije do Bosne i Hercegovine“, te "Ponešto još o mađarskom projektu „Julijanske akcije“" u Bosni i Hercegovini“". Autor baca historijski pogled na razdoblje kraja XIX i početka XX stoljeća u kontekstu fenomena brige za narodom izvan matične zemlje. Radi se, konkretno, o projektu mađarske (ugarske) vlade, prozaičnog naziva „Julijanska akcija“. Autor ističe da su ove i slične akcije ponekad politički dirigirane iz centara moći Austro-Ugarske na prostor Bosne i Hercegovine te Hrvatske i Slavonije. 
Igor Mišković je napisao rad pod naslovom Uticaj časopisa Pregled na društveni i kulturni život Bosne i Hercegovine kroz pisanje o agrarnoj problematici 1910-1913. (120-132). Riječ je o časopisu za društvena pitanja koji je poslije Glasnika Zemaljskog muzeja drugi najstariji časopis u Bosni i Hercegovini. Pored uvoda, autor nas kroz četiri poglavlja provodi kroz navedeni časopis. U poglavlju Državno-pravni položaj i agrarno pitanje u Bosni i Hercegovini autor ističe da je epicentar političkih, nacionalnih i ekonomskih previranja u Bosni i Hercegovini krajem XIX i u prvoj deceniji XX stoljeća bilo agrarno pitanje. Drugo poglavlje Pregled o agrarnoj problematici u Bosni i Hercegovini (1910-1913) govori o cilju pokretanja časopisa, urednicima, rukovodiocima, karakteru časopisa te o mjestu štampanja istog u navedenom periodu. Zadnja dva poglavlja ovog rada predstavljaju prikaz agrarnog pitanja kroz Pregled u periodu do donošenja i nakon donošenja Zakona o fakultativnom otkupu kmetskih selišta. Na kraju autor zaključuje da je, pored aktualnih dešavanja u Bosni i Hercegovini Pregled zainteresovane informisao i o ključnim društveno-političkim kretanjima u cijeloj Evropi. Autor govori da stvarne razloge zbog kojih je Pregled, 1. aprila 1913. godine prestao sa izlaženjem nije bilo moguće objektivno utvrditi.

$\mathrm{U}$ radu prof. dr. Izeta Šabotića pod nazivom Agrarne prilike u Semberiji u prvom desetljeću 20. stoljeća (133-152) predstavljen je Memorandum iz 1912. godine Osman-bega Pašića, zemljoposjednika iz Bijeljine, koji je upućen zajedničkom ministru finansija Bilinskom. Autor, iz ugla Memoranduma, govori o brojnim poteškoćama sa kojima se susreću bošnjački zemljoposjednici i Bošnjaci u Semberiji. Posebno naglašava istaknuti problem odnosa čifčije i age zemljoposjednika, gdje je do izražaja došlo nepoštivanje obaveza od strane čifčija, te uzurpaciji imovine. Autor ističe da je ovaj dokument samo jedan u nizu dokumenata koji potvrđuju svu kompleksnost i slojevitost agrarnih odnosa u Bosni i Hercegovini u ovom periodu, koji su, po njegovim riječima, bili posebno složeni na području Semberije.

Tragom pisane riječi vjerske inteligencije Bošnjaka u austrougarskom razdoblju i njihova prosvjetiteljska uloga rad je dr. sc. Edina Veladžića (153-173) u kojem se nudi kratak osvrt na značaj i ulogu vjerske inteligencije Bošnjaka na polju afirmacije pisane riječi u austrougarskom razdoblju. U fokusu rada je intelektualni aktivizam bošnjačke vjerske inteligencije $u$ austrougarskom razdoblju sa posebnim osvrtom na njeno učestvovanje u, kako autor kaže, društveno-civilizacijskom izazovu koji se zove štampa i izdavačka djelatnost. Autor nam eksplicitno objašnjava zašto se radi o izazovu ističući nužnost uzimanja u obzir činjenicu da je tadašnja vjerska inteligencija Bošnjaka cijeli svoj formalni obrazovni proces završila u školama orijentalnog tipa što je za direktnu posljedicu imalo neuporedivo bolje snalaženje u pisanju na stranim jezicima (turskom, arapskom i perzijskom) nego na bosanskom. Kao primjer autor nam navodi problem Mehmeda Džemaludin ef. Čauševića koji je nakon povratka iz Istanbula, kao i druge hodže koje su se tamo školovale, slabo poznavao naš jezik. Osim Čauševića, autor podsjeća na pisanu riječ 
i drugih bošnjačkih intelektualaca kao što su: Seid ef. Serdarević, Šukrija Alagić, Muhamed Emin ef. Dizdar, Ali ef. Kadić, Sakib ef. Korkut, Hasan ef. Nametak, Ibrahim ef. Repovac, Muhamed ef. Zahirović, Abdurahman Adil Čokić, Sejfudin ef. Kemura, Hasan ef. Spaho, Osman Nuri Hadžić, Salih Sidki ef. Hadžihuseinović Muvekit itd.

Prof. dr. Adnan Velagić donosi rad pod naslovom Atentat u Sarajevu $i$ njegove refleksije na području Hercegovine (174-193). Autor je nastojao da na osnovu arhivske građe, koja do sada nije objavljena, osvijetli događaje iz ovog burnog vremena na području Hercegovine. Koristeći fondove Arhiva Hercegovačko-neretvanskog kantona (Gradski odbor Trebinje i Okružni sud Mostar) autor nas upoznaje sa vojnim pripremama za rat na području Hercegovine te društvenim kretanjima u Hercegovini poslije atentata.

Rad mr. sc. Omera Zulića pod naslovom Ulazak Bosne i Hercegovine $u$ Kraljevinu Srba, Hrvata i Slovenaca prema pisanju Narodnog jedinstva (194-212) prati informacije sadržane u kolumnama navedenog glasila od 4. novembra, kada je izašao prvi broj Narodnog jedinstva, pa do 26. decembra 1918. godine. Osim uvodnih napomena rad sačinjavaju dva poglavlja: Djelatnost Narodnog vijeća SHS za Bosnu i Hercegovinu, te Ulazak Bosne i Hercegovine u Kraljevinu Srba, Hrvata $i$ Slovenaca, naravno prema pisanju Narodnog jedinstva. Iz sadržaja ovog rada, kojeg autor donosi onako kako zahtijeva historijska kritika, nije teško zaključiti da je Narodno jedinstvo prorežimski medij i da se radi o medijskom prostoru veličanja novog poretka, ideje ujedinjenja i svega što je nosilo prefiks srpskog. S toga, zaključuje autor, korištenje Narodnog jedinstva u naučno-istraživačkom procesu podrazumijeva obavezno kritički pristup, te komparativni metod, sa svim ostalim, relevantnim, dostupnim historijskim izvorima.

U službi ideje „narodnog $i$ državnog jedinstva“: školstvo u Bosni $i$ Hercegovini od 1918. do 1929. godine rad je prof. dr. Seada Selimovića (213229). Autor u ovom radu posvećuje pažnju jednom od najvažnijih pitanja iz savremene povijesti Bosne i Hercegovine, a to je pitanje školstva. U ovom radu autor baca kritički pogled na (ne)razvoj školstva u Bosni i Hercegovini od nastanka Kraljevstva SHS pa do 1929. godine. Nakon ulaska Bosne i Hercegovine u sastav novoformirane države 1918. godine desile su se brojne promjene u organizaciji i radu osnovnih i srednjih škola. One su se, prevashodno, ogledale u nastojanju vladajuće elite da stvori, pored političkog, jedinstven obrazovni i kulturni prostor. U grupi nacionalnih predmeta izvršene su promjene tako što je akcenat stavljen na historiju i geografiju Srba, Hrvata i Slovenaca, a za školsku lektiru su propisana djela iz srpske, hrvatske ili slovenačke književnosti. Osim navedenog, autor ovog članka govori o ukazivanju bosanskohercegovačkih intelektualaca na slabosti školstva. Edhem Mulabdić, Juraj Puljić, poslanik Husejn Alić, te brojni drugi ukazivali su na slabosti u školstvu te nudili rješenja. Međutim, ističe autor, vladajuće elite se nisu mnogo osvrtale na to. Autor zaključuje da se stanje u oblasti prosvjetne politike sporo mijenjalo i išlo je u pravcu unifikacije na cijelome prostoru Kraljevine Srba, Hrvata i Slovenaca. 
Prof. dr. Omer Hamzić napisao je rad Jedan pogled na život $i$ djelo akademika Mustafe Kamarića (230-241). Rad predstavlja kratak osvrt autora na život i djelo Mustafe Kamarića, skoro zaboravljenog profesora Pravnog fakulteta u Sarajevu i dopisnog člana Akademije nauka i umjetnosti Bosne i Hercegovine. U uvodnim napomenama autor nas upoznaje sa nekim osnovnim biografskim podacima akademika M. Kamarića, od kojih izdvajamo da je rođen u Gračanici 7. aprila 1906. godine gdje je završio osnovnu školu. Nakon toga je završio Šerijatsku gimnaziju u Sarajevu, a potom i Pravni fakultet u Beogradu. Doktorat pravnih nauka stekao je (prije 1957. godine) u Zagrebu. U nastavku rada autor nam govori o mladim danima kada je Mustafa Kamarić nastojao unaprijediti kulturno-zabavni život u rodnoj Gračanici što dokazuje osnivanje kulturno-prosvjetnog društva „Narodna biblioteka“ 1924. godine. Na osnovu izvora sa Pravnog fakulteta u Beogradu autor nam, u nastavku, predstavlja studentski život Mustafe Kamarića. Osim podatka da je Mustafa bio jedan od najvrijednijih članova beogradskog „Gajreta“, smatramo važnim izdvojiti i to da je Glavni odbor „Gajreta“ poslao svog afirmisanog pitomca na specijalističke studije u Kairo. U narednom poglavlju autor se osvrće na profesionalni angažman Kamarića u mnogim državnim organima i tijelima republičkog i saveznog značaja dajući tako veliki doprinos izgradnji pravnog poretka u Bosni i Hercegovini. Na kraju autor predstavlja Mustafu Kamarića i kao Visokog funkcionera Islamske zajednice u Bosni i Hercegovini ističući njegovo članstvo u Vrhovnom saboru Islamske zajednice, te članstvo u Vrhovnom islamskom starješinstvu.

Bosna u osmanističkom fokusu: paralele jugoslovenskog $i$ postjugoslovenskog perioda rad je dr. sc. Ramize Smajić (242-249). U radu je pažnja posvećena osmanističkoj obradi bosanskog prostora u različitim društvenim okvirima, finansijskim i kadrovskim kapacitetima, afinitetima i ideološkim usmjeravanjima. Kao inicijalni motiv ovom radu autorica navodi mudrost: $D a$ bi porazio jedan narod, dovoljna je jedna bitka u kojoj ćeš ga pobijediti. Da bi potpuno porobio i potčinio jedan narod, samo mu napiši historiju. Autorica ukazuje na problem ideološke uslovljenosti razvoja osmanistike u Bosni i Hercegovini ističući karakter i realizaciju samog odnosa bosanskohercegovačkih osmanista prema bosanskom prostoru. $\mathrm{S}$ tim $\mathrm{u}$ vezi, autorica navodi nekoliko primjera $\mathrm{u}$ osmanističkim radovima. Prvo, među zajedničkim masovno prihvaćenim navikama osmanista jugoslavenskog i postjugoslavenskog doba jeste perspektiva bosanskog prostora iz sadašnjosti sa beskrupuloznom upotrebom naziva države Bosna i Hercegovina kao kontinuiranog tako kompaktnog izraza od najstarijih vremena i nikakvom opravdanošću za period koji se pokušava rasvijetliti. Drugo: poslije rata 1992-1995. osmanistika obolijeva od bolesti koja rijetko pogađa rad nebosanskih naučnika - od lokalizacije! Treće, autorica govori o jednoj čudnoj neinvetivnosti i nezainteresiranosti bosanskohercegovačkih osmanista u traganju za odgovorima na brojna namjerno ili stihijski zaobiđena pitanja. U prilog tome autorica postavlja pitanje da li smo se ikad zapitali zašto je Putopis Evlije Čelebije kod nas ostao samo u svom djelimičnom prevodu? 
Rad mr. Semira Hadžimusića pod naslovom Opismenjavanje stanovništva Bosne i Hercegovine u periodu narodnooslobodilačkog rata (1941-1945) (250277) predstavlja stanje pismenosti stanovništva Bosne i Hercegovine do Drugog svjetskog rata, te posebno prezentira aktivnosti vezane za opismenjavanje stanovništva u periodu NOR-a. Autor se osvrće i na opismenjavanje stanovništva preraslog za redovnu osnovnoškolsku nastavu, te na aktivnosti koje su tim povodom odvijane u okviru NOP-a na području Bosne i Hercegovine. Podnaslovom $O$ prosvjetnoj politici Nezavisne Države Hrvatske autor upotpunjuje sliku o ovom procesu na području Bosne i Hercegovine.

Rad prof. dr. Denisa Bećirovića pod naslovom Ibrahim ef. Fejić - prvi reisul-ulema u Titovoj Jugoslaviji (278-299) analizira i prikazuje aktivnosti prvog poslijeratnog reisul-uleme u Titovoj Jugoslaviji u kontekstu političkih, ali i ukupnih historijskih okolnosti. S tim u vezi, autor je osim kratkih biografskih podataka reisul-uleme, predstavio historijski kontekst u kojem je reis Fejić djelovao, zatim njegove stavove o pravnom položaju vjerskih zajednica. Osim toga, autor je analizirajući sadržinu govora reisa Fejića prilikom svečane mu predaje Menšure 12. septembra 1947. godine ukazao u kakvom nezavidnom položaju se nalazila Islamska zajednica u prvim poslijeratnim godinama. U nastavku rada autor prikazuje angažman reisul-uleme Fejića na formiranju Udruženja ilmije u Bosni i Hercegovini iznoseći stav da je udruženje bilo u funkciji političkog promoviranja i podrške razvoju novog društveno-političkog poretka. U prilog tome autor spominje dopis sekretara Udruženja Sulejmana Kemure kojeg je uputio predsjedniku Državne komisije za vjerska pitanja sredinom oktobra 1950. godine. Koristeći se primarnim izvorima iz Arhiva Jugoslavije autor nam na kraju predstavlja vanjskopolitičku aktivnost reisa Ibrahima ef. Fejića. Ilustrativno, autor navodi da je od decembra 1952. do decembra 1953. godine reisul-ulema primio 23 strane delegacije i javna radnika, među kojima su bili poznati književnici tog doba, ministri, generali, visoki diplomatski predstavnici, novinari poznatih medija (BBC, časopis Republika itd). Na kraju, raspravljajući o aktivnostima i učešću Islamske zajednice u okviru jugoslovenske vanjske politike, autor napominje da ova zajednica nije bila samo orijentirana na pitanja vezana za islamske zemlje. U tom kontekstu, autor navodi oštru reakciju reisul-uleme Fejića prilikom predaje zone A Slobodne teritorije Trsta u kojoj izjavljuje da se poslijeratna „klerofašistička Italija ne razlikuje po svojim imperijalističkim aspiracijama od Musolinijeve Italije“.

„Godina raspleta“ - Jugoslavija 1968: studentske demonstracije $i$ tuzlanske reakcije rad je autora mr. Jasmina Jajčevića (300-321) u kojem se, na osnovu štampe te pisama i telegrama, predstavljaju reakcije radnika preduzeća i kolektiva rudara, prevashodno, rudnika uglja „Tito“ Banovići i rudnika „Kreka“, na demonstracije studenata u Beogradu. Pored reakcije tuzlanskih visokoškolaca autor donosi i reakciju radnog kolektiva Osnovne škole „Franjo Rezač“ Kreka gdje se, između ostalog, kaže: „i mi imamo poteškoća na planu obrazovanja i vaspitanja, ali ih rješavamo jedino putem dogovora sa samoupravnim institucijama." Autor navodi i poruku koju su radnici škole poslali studentima. Ona se sastojala u 
tome da najveću pomoć društvu mogu pružiti ako na vrijeme završe studije i što prije se uključe u ostvarivanje društvene i privredne reforme. Na kraju rada autor predstavlja Osobenosti i značaj studentskog pokreta u Jugoslaviji ističući da studentski pokret u Jugoslaviji nije ni u jednom trenutku pokazao otpor prema Titu i njegovom autoritetu u društvu, a još manje bi se moglo govoriti i o nekakvoj namjeri da se u pobuni izvrši destrukcija tog autoriteta. Zaključno, autor dijeli uzroke demonstracija u nekoliko razina: materijalna situacija i akademsko okruženje studenata na univerzitetu u sklopu samoupravnih odnosa te perspektiva nakon studija i mogućnosti za zaposlenje što je, kako kaže autor, bilo povezano s trenutnim privrednim prilikama.

Dr. sc. Dženita Sarač-Rujanac donosi rad na temu Politički zemljotres u SR Bosni i Hercegovini nakon oktobra 1969. godine. Odnos republičkog i saveznog rukovodstva početkom 1970-tih godina (322-344). U radu se prate višemjesečni pregovori oko izvora finansiranja, udjela Federacije i drugih republika u obnovi i izgradnji Bosanske krajine te se ukazuje na političke posljedice zemljotresa u Banja Luci 1969. godine.

$\mathrm{U}$ radu dr. sc. Filipa Škiljana pod naslovom Migracije Muslimana iz Zapadne Bosne na područje Banije i Korduna u socijalističkom periodu i vjersko organiziranje vjernika islamske vjeroispovjesti u Sisku i Kordunu (345-363) predočene su informacije o doseljavanju Muslimana na područje Siska i okolice i na teritorij Korduna (općine Vrgin most, Vojnić i Slunj). Na osnovu usmenih iskaza kazivača iz više kordunskih naselja i kazivača iz Siska i Mošćenice autor donosi podatke o okolnostima doseljavanja i odnosima s lokalnim stanovništvom nakon doseljavanja. $\mathrm{Na}$ temelju arhivskog materijala iz Mešihata Islamske zajednice u Zagrebu i Džemata Sisak autor nam u drugom dijelu rada donosi podatke o početku organiziranja džemata u Sisku, u Maljevcu i u Bogovolji.

Mr. Jasmin Medić donosi rad na temu: Utjecaj rata u Hrvatskoj na zbivanja u Bosanskoj krajini 1991. godine (364-374) u kojem analizira utjecaj ratnih dešavanja u Hrvatskoj na nacionalne odnose u Bosanskoj krajini 1991. godine. Autor piše da je proces proglašenja autonomnih oblasti u Bosni i Hercegovini započet po uzoru na Srpsku autonomnu oblast (SAO) Krajinu proglašenu u Kninu 19. decembra 1990. godine. Prvo proglašenje jedne takve tvorevine u Bosni i Hercegovini bilo je 29. aprila 1991. godine kada je obrazovana Zajednica opština Bosanske krajine (ZOBK) u čiji sastav ulaze opštine sjeverozapadne Bosne i u kojima je srpsko stanovništvo bilo većinsko. Autor piše o razlogu nepostojanja ozbiljnijeg suprotstavljanja politici SDS-a Bosne i Hercegovine, te o saradnji SAO Krajine i $Z O B K$-a što je rezultiralo Deklaracijom o ujedinjenju „dvije krajine“ od 27. juna 1991. godine u kojoj je naglašeno da je ,ujedinjenje srpstva imperativ“. U nastavku rada autor piše o mobilizaciji u JNA i incidentima u Bosanskoj krajini. Na kraju autor piše o problemu izbjeglica s kojim se suočila Bosanska krajina zbog ratnih zbivanja u Hrvatskoj. Prema određenim podacima, navodi autor, do kraja 1991. godine u Bosanskoj krajini bilo je oko 45.000 izbjeglica iz reda sva tri naroda. 
Rad dr. sc. Senije Milišić pod naslovom Etničko čišćenje bošnjačkog stanovništva 1992-1995. (metodi, pravci, statistički pokazatelji)(375-413) jeste dio njene znanstvene trilogije koja tretira razmjere i strahote počinjenih zločina u Bosni i Hercegovini 1992-1995. godine. Pored uvodnih napomena, gdje je autorica ukazala da proces etničkog čišćenja predstavlja u suštini proces višestrukih zločina, te da je poslije 1995. godine preko 70\% teritorije Bosne i Hercegovine bilo etnički očišćeno od Bošnjaka, u prvom poglavlju ovog rada eksplicitno se predstavlja programska matrica etničkog čišćenja polazeći od političkog programa Ilije Garašanina iz 1844. godine poznatom kao Načertanije. Autorica ističe da su Čubrilovićev i Moljevićev program, zatim Memorandum SANU u suštini razrada temeljnog programa Načertanija, ali i operacionalizacija u smislu pretakanja u Direktive, Instrukcije, Naredbe i Strateške ciljeve, kako 1941. tako i 1992. godine. Također, autorica govori o sprezi dva projekta ističući da na svako aktueliziranje $i$ doradu srpskog projekta uslijedio bi odgovor hrvatske strane. U poglavlju Put $u$ istrebljenje, autorica ovog rada nas uvodi u posljednju fazu raspada Jugoslavije (raspad SKJ - 14. kongres) ukazujući da su promjene na političkom planu pratile i promjene u JNA. S tim u vezi, autorica ističe da su političke aktivnosti Srba u Bosni i Hercegovini (SDS) pratile i aktivnosti JNA, a sve koordinirane iz centra u Beogradu. U nastavku rada autorica govori o samom protjerivanju stanovništva posvećujući posebnu pažnju primjeru Bijeljine iz kojeg se, po njenim riječima, da iščitati obrazac kasnijih djelovanja JNA i „paravojnih“ jedinica. U poglavlju Formiranje VRS - dovršetak etničkog čišćenja, ukazuje se na značaj dva događaja iz maja 1992. godine koja su bila opredjeljujuća za dalji tok rata. Radi se o sastanku Karadžića i Bobana u Gracu i zasjedanju Skupštine srpskog naroda u Bosni i Hercegovini. U nastavku autorica piše o stvaranju administrativno teritorijalne jedinice hrvatske zajednice Herceg Bosna, neposredno nakon proglašenja srpskih autonomnih oblasti (SAO), čime je potvrdila svoju konstataciju o savezu dva projekta. Na kraju, umjesto zaključka, autorica ovog rada govori o posljedicama etničkog čišćenja od kojih izdvajamo: Bošnjaci su nakon potpisivanja Dejtonskog mirovnog sporazuma svedeni na $25-27 \%$ teritorije; procjenjuje se da je preko 30.000 Bošnjakinja silovano; sa svojih ognjišta pokrenuto je 2,2 miliona stanovnika Bosne i Hercegovine (oko 63\% Bošnjaci).

Granični sporovi Bosne i Hercegovine sa Republikom Hrvatskom rad je prof. dr. Seada Omerbegovića i dr. sc. Izudina Šarića (414-429) u kojem autori analiziraju ugovor o državnoj granici između Bosne i Hercegovine i Republike Hrvatske potpisan 30. jula 1999. godine. S tim u vezi, autori ističu da nijedan dokument vezano za granicu s Hrvatskom do sada nije ratificiran u Parlamentarnoj skupštini Bosne i Hercegovine kao ni u Hrvatskom saboru i da je, praktično, čitava granična linija s Hrvatskom otvoreno pitanje. U posebnom poglavlju autori pišu o međudržavnoj diplomatskoj komisiji za provedbu ugovora, njenom ustrojstvu, načinu rada te o graničnim dokumentima potvrđenim od strane ove komisije na 12. sjednici, održanoj u Sarajevu 24. marta 2005. godine. Navedeni granični 
dokumenti, uz 86 topografskih karata razmjera 1:25000 na kojima je prikazana državna granica, sastavni su dio ugovora. U nastavku rada autori ističu dvije sporne tačke državne granice Republike Hrvatske i Bosne i Hercegovine. Radi se o Kostajnici te o poluotoku Klek kao jednoj od spornih tačaka morske granice Bosne i Hercegovine i Republike Hrvatske.

U drugom dijelu časopisa Historijski pogledi, prikazano je nekoliko značajnih publikacija izašlih u periodu od 2016. do 2019. godine. Prof. dr. Sead Selimović je prikazao knjigu Senaida Hadžića, Primjeri suživljenja: bilješke o tuzlanskom kraju u 19. stoljeću. Knjiga je izašla u Tuzli 2017. godine, a izdavači su Arhiv Tuzlanskog kantona, Centar za istraživanje moderne i savremene historije Tuzla, te Društvo arhivskih zaposlenika Tuzlanskog kantona. Knjigu profesora Izeta Šabotića, Čifčijski odnosi i promjena vlasništva nad zemljom u Bosni i Hercegovini (1878-1918) prikazao je Amir Krpić. Knjiga je izdata u Tuzli 2019. godine, a izdavač je Centar za istraživanje moderne i savremene historije Tuzla. Mr. sc. Omer Zulić prikazao je knjigu od Damira Bošnjakovića, Tojšići od srednjeg vijeka do 1958. godine, Knjiga Prva, Arhiv Tuzlanskog kantona, Centar za istraživanje savremene i moderne historije Tuzla, JU Bosanski kulturni centar „Alija Izetbegovićc Kalesija, Tuzla 2018. Mr. Jasmin Jajčević je prikazao, Zbornik radova Na margini povijesti, Edicija Zbornici, knjiga 5, Udruženje za modernu historiju Sarajevo, Sarajevo 2018. Adnan Tinjić je prikazao knjigu od profesora Adnana Jahića, Muslimansko žensko ppitanje u Bosni i Hercegovini (1908-1950), Bošnjačka nacionalna zajednica za Grad Zagreb i Zagrebačku županiju, Zagreb 2017. Knjigu dr. Fikreta Karčića, Pravno-historijske studije prikazao je mr. Sead Bandžović. Knjiga je izdata u produkciji Centra za napredne studije u Sarajevu 2016. godine.

U trećem dijelu časopisa pod naslovom Izvještaji, mr. Jasmin Jajčević je donio izvještaj sa naučne manifestacije „Historijski pogledi“, Tuzla, 8. i 9. novembar 2018. godine. Konkretno Jajčević je govorio o naučnoj konferenciji pod nazivom Bosna i Hercegovina 1878-2018. - politički i društveni procesi koja je realizirana u okviru naslovljene naučne manifestacije.

I na kraju, u časopisu Historijski pogledi, predstavljene su Aktivnosti Centra za istraživanje moderne i savremene historije Tuzla u 2018. godini. 